\title{
Correction: Casein kinase 2 inhibition sensitizes medulloblastoma to temozolomide
}

\author{
Ryan T. Nitta ${ }^{1}$ - Sara Bolin $\mathbb{1}^{1}$ - Emily Luo ${ }^{1}$ - David E. Solow-Cordero ${ }^{2}$ - Peyman Samghabadi ${ }^{3}$ Teresa Purzner ${ }^{4,5}$. \\ Parvir S. Aujla ${ }^{1} \cdot$ Ginikachi Nwagbo $^{1} \cdot$ Yoon-Jae $\mathrm{Cho}^{6} \cdot{\text { Gordon } \mathrm{Li}^{1}}^{1}$
}

Published online: 28 October 2019

(c) The Author(s) 2019. This article is published with open access

\section{Correction to: Oncogene}

https://doi.org/10.1038/s41388-019-0927-y

The original version of this article contained an error in the spelling of the author David Solow-Cordero, which was incorrectly given as David Solow-Codero.
Ryan T. Nitta

rnitta@stanford.edu

1 Department of Neurosurgery, Stanford University, Stanford, CA, USA

2 High-Throughput Bioscience Center, Department of Chemical and Systems Biology, Stanford University, Stanford, CA, USA

3 Department of Neuropathology, Stanford University, Stanford, CA, USA

4 Department of Developmental Biology, Stanford University, Stanford, CA, USA

5 Division of Neurosurgery, University of Toronto, Toronto, ON, Canada

6 Department of Pediatrics, Papé Family Pediatric Research Institute, Knight Cancer Institute, Oregon Health \& Science University, Portland, OR, USA
Open Access This article is licensed under a Creative Commons Attribution 4.0 International License, which permits use, sharing, adaptation, distribution and reproduction in any medium or format, as long as you give appropriate credit to the original author(s) and the source, provide a link to the Creative Commons license, and indicate if changes were made. The images or other third party material in this article are included in the article's Creative Commons license, unless indicated otherwise in a credit line to the material. If material is not included in the article's Creative Commons license and your intended use is not permitted by statutory regulation or exceeds the permitted use, you will need to obtain permission directly from the copyright holder. To view a copy of this license, visit http://creativecommons. org/licenses/by/4.0/. 